\title{
Enhancement of proinflammatory and procoagulant responses to silica particles by monocyte-endothelial cell interactions
}

\author{
Xin Liu, Yang Xue, Tingting Ding and Jiao Sun ${ }^{*}$
}

\begin{abstract}
Background: Inorganic particles, such as drug carriers or contrast agents, are often introduced into the vascular system. Many key components of the in vivo vascular environment include monocyte-endothelial cell interactions, which are important in the initiation of cardiovascular disease. To better understand the effect of particles on vascular function, the present study explored the direct biological effects of particles on human umbilical vein endothelial cells (HUVECs) and monocytes (THP-1 cells). In addition, the integrated effects and possible mechanism of particle-mediated monocyte-endothelial cell interactions were investigated using a coculture model of HUVECs and THP-1 cells. $\mathrm{Fe}_{3} \mathrm{O}_{4}$ and $\mathrm{SiO}_{2}$ particles were chosen as the test materials in the present study.

Results: The cell viability data from an MTS assay showed that exposure to $\mathrm{Fe}_{3} \mathrm{O}_{4}$ or $\mathrm{SiO}_{2}$ particles at concentrations of $200 \mu \mathrm{g} / \mathrm{mL}$ and above significantly decreased the cell viability of HUVECs, but no significant loss in viability was observed in the THP-1 cells. TEM images indicated that with the accumulation of $\mathrm{SiO}_{2}$ particles in the cells, the size, structure and morphology of the lysosomes significantly changed in HUVECs, whereas the lysosomes of THP-1 cells were not altered. Our results showed that reactive oxygen species (ROS) generation; the production of interleukin (IL)-6, IL-8, monocyte chemoattractant protein 1 (MCP-1), tumor necrosis factor (TNF)-a and IL-1 $\beta$; and the expression of CD106, CD62E and tissue factor in HUVECs and monocytes were significantly enhanced to a greater degree in the $\mathrm{SiO}_{2}$-particle-activated cocultures compared with the individual cell types alone. In contrast, exposure to $\mathrm{Fe}_{3} \mathrm{O}_{4}$ particles had no impact on the activation of monocytes or endothelial cells in monoculture or coculture. Moreover, using treatment with the supernatants of $\mathrm{SiO}_{2}$-particle-stimulated monocytes or HUVECs, we found that the enhancement of proinflammatory response by $\mathrm{SiO}_{2}$ particles was not mediated by soluble factors but was dependent on the direct contact between monocytes and HUVECs. Furthermore, flow cytometry analysis showed that $\mathrm{SiO}_{2}$ particles could markedly increase CD40L expression in HUVECs. Our data also demonstrated that the stimulation of cocultures with $\mathrm{SiO}_{2}$ particles strongly enhanced c-Jun $\mathrm{NH}_{2}$-terminal kinase (JNK) phosphorylation and NF-KB activation in both HUVECs and THP-1 cells, whereas the phosphorylation of p38 was not affected.

Conclusions: Our data demonstrate that $\mathrm{SiO}_{2}$ particles can significantly augment proinflammatory and procoagulant responses through CD40-CD40L-mediated monocyte-endothelial cell interactions via the JNK/NF-KB pathway, which suggests that cooperative interactions between particles, endothelial cells, and monocytes may trigger or exacerbate cardiovascular dysfunction and disease, such as atherosclerosis and thrombosis. These findings also indicate that the monocyte-endothelial cocultures represent a sensitive in vitro model system to assess the potential toxicity of particles and provide useful information that may help guide the future design and use of inorganic particles in biomedical applications.
\end{abstract}

Keywords: Endothelial cells, Monocytes, Inflammation, Particles, Cell-cell interaction, Signal transduction

\footnotetext{
* Correspondence: jiaosun59@yahoo.com

Shanghai Biomaterials Research \& Testing Center, Shanghai Key Laboratory of Stomatology, Ninth People's Hospital, Shanghai Jiaotong University School of Medicine, No. 427, Ju-men Road, Shanghai 200023, China
} 


\section{Background}

Due to their excellent mechanical stability, high carrier capacity, easy variation of surface properties and inexpensive synthesis, inorganic nanoparticles have been widely studied in various medical fields, such as drug delivery, the discovery of biomarkers, and molecular diagnostics and gene therapy [1]. Before nanoparticles are used for medical applications, their biological behavior and toxicological properties must be carefully assessed. Thus, it is necessary to understand the interactions of nanoparticles with biological systems.

For many intravenously administered nanoparticlebased drug carriers, the prolonged circulation properties can lead to the controlled release of therapeutic agents in the blood to targeted cells. However, the extended circulation time may increase the duration of the particles' contact with blood components and endothelium and potentially cause undesirable host responses. Monocytes are among the first immune cells recruited to an invasion site in response to foreign materials. Recently, many studies have focused on nano-immunotoxicity and have found that some inorganic particles (e.g., hydroxyapatite particles, Nano-Co, and quantum dots) can activate monocytes to increase the release of proinflammatory cytokines and reactive oxygen species (ROS) [2-4]. Monocytes are a commonly used in vitro model for the innate immune response within a single cell type, but in the case of barrier defense, more complex models are required [5]. The endothelium not only serves as a natural barrier in controlling the passage of particles from the blood into the surrounding tissues but also intricately links to innate immunity. Previous studies have shown that most inorganic particles (e.g., silica, zinc oxide, and alumina particles) can initiate an inflammatory response in endothelial cells (ECs), including the secretion of proinflammatory cytokines and the upregulation of vascular cellular adhesion molecule-1 (VCAM-1), intercellular adhesion molecule-1 (ICAM-1) and E-selectin, which are responsible for monocyte recruitment and adhesion [6-8]. Monocyte-endothelial cell adhesion and interactions have long been recognized for their essential roles in the process of inflammation and thrombosis [9]. However, to date, while the direct effects of particles on ECs and monocytes have been widely discussed, far less effort has been put forth concerning the question of whether the particles can indirectly influence the host immune response through ECs or indirectly induce endothelial cell dysfunction via monocytes. Thus, the functional consequences and precise mechanisms of particle-induced monocyte-endothelial cell interactions must be further investigated. Ongoing applications of engineered nanoparticles in drug delivery systems and the molecular imaging field increase the urgency of such studies. In general, the interactions between monocytes and ECs may be direct, through ligand-receptor interactions, or indirect, through released factors (e.g., cytokines, growth factors or ROS). [10,11] Recently, it has been reported that CD40/CD40L-mediated costimulation between monocytes and ECs leads to the induction of inflammatory and adhesive proteins in both cell types $[12,13]$. Moreover, there is increasing evidence that particles can effectively upregulate CD40 expression in immune cells $[14,15]$. Thus, it is likely that both soluble factors and costimulatory molecules play critical roles in particle-mediated monocyte-endothelial cell interactions, and further investigations are required to support this hypothesis.

Metal and silica particles $\left(\mathrm{SiO}_{2}\right.$ particles) are among the most promising inorganic particles being developed for target therapy or molecular imaging [16-18]. Thus, $\mathrm{Fe}_{3} \mathrm{O}_{4}$ and $\mathrm{SiO}_{2}$ particles were chosen as test materials in the present study. As drug carriers or contrast agents, the distribution of particles into the vascular system appears highly probable. In our previous studies, we have found that $\mathrm{SiO}_{2}$ particles could directly induce inflammatory activation in ECs by the NF- $\mathrm{BB}$ pathway [8]. Here, considering the complex architecture of the vascular system, we established a coculture model of THP-1 cells (monocytes) and human umbilical vein endothelial cells (HUVECs) to mimic the in vivo situation and, for the first time, investigated the integrated effects and possible mechanisms of the interactions between particles, monocytes and ECs. First, we assessed the direct effects of particles on THP-1 cells and HUVECs through the observation of cellular uptake and changes in cell viability. Subsequently, to investigate the functional consequences and molecular mechanisms of particle-mediated monocyte-endothelial cell interactions, we measured ROS levels, the release of proinflammatory cytokines, cellular adhesion molecules (CAMs), procoagulant marker expression, mitogen-activated protein kinases (MAPK), and the NF-kB activation of monocytes and ECs in particles-stimulated mono- and cocultures. Moreover, to determine the role of soluble factors and cell-to-cell contact in particle-induced monocyte-endothelial cell interactions, we used the supernatant from THP-1 cells that had been stimulated with particles to treat HUVECs and vice versa and then examined the proinflammatory and procoagulant responses. In addition, to investigate the cell-to-cell contact-dependent mechanism, we also measured CD40L and CD40 expression in particle-stimulated THP-1 cells and HUVECs. Our studies provide a better understanding of the impact of nanoparticles on monocyte-endothelial cell interactions, which aids in the design of nanoparticles for various applications, including drug delivery or molecular imaging, especially when the cellular microenvironment near an atherosclerotic plaque site must be considered. 


\section{Results and discussion}

Prior to investigating the biological effects of particles used in the current studies, the particles were characterized with a transmission electron microscope (TEM), dynamic light scattering (DLS), and nitrogen adsorptiondesorption isotherms. The TEM analysis revealed that the primary size of $\mathrm{SiO}_{2}$ and $\mathrm{Fe}_{3} \mathrm{O}_{4}$ particles was approximately $20 \mathrm{~nm}$ and $25 \mathrm{~nm}$ in diameter, respectively, and the shape was near spherical (Figure 1A-B). In aqueous systems, nanoparticles have a tendency to aggregate. Therefore, the secondary particles' size in aqueous solutions (the hydrodynamic size) might also be an important factor affecting their biological behaviors. As shown in Figure $1 \mathrm{C}$, the hydrodynamic size was $102 \mathrm{~nm}$ in EC medium (ECM) and $93 \mathrm{~nm}$ in RPMI 1640 medium with $10 \% \mathrm{FBS}$ for $\mathrm{SiO}_{2}$ particles, and $564 \mathrm{~nm}$ in ECM and $480 \mathrm{~nm}$ in RPMI 1640 medium with $10 \% \mathrm{FBS}$ for $\mathrm{Fe}_{3} \mathrm{O}_{4}$ particles. Subsequently, the measurement of zeta potential was also used to study the agglomeration and dispersion stability of the colloidal system. The higher the zeta potential, the more likely that the suspension is stable. In general, particle suspensions with an absolute zeta potential value above $30 \mathrm{mV}$ are normally considered stable. Consistent with the DLS measurement results, $\mathrm{Fe}_{3} \mathrm{O}_{4}$ particles had the lowest absolute magnitude of zeta potential (12 $\mathrm{mV}$ in ECM and $15 \mathrm{mV}$ in RPMI), followed by $\mathrm{SiO}_{2}$ particles ( $35 \mathrm{mV}$ in ECM and $38 \mathrm{mV}$ in RPMI), indicating that $\mathrm{SiO}_{2}$ particles have a lower degree of agglomeration and higher dispersion stability than $\mathrm{Fe}_{3} \mathrm{O}_{4}$ particles in culture media. Most studies have demonstrated that the agglomeration of particles results in a decrease in the associated toxicity $[19,20]$. However, recent studies have found that agglomerated $\mathrm{SiO}_{2}$ particles induce more potent proinflammatory cytokine responses than non-agglomerated particles, indicating that avoiding agglomeration may lead to an underestimation of the possible adverse effects [21]. Thus, it might be more important to conduct a thorough characterization of the agglomeration states than to maintain a single-particle preparation when analyzing the potential health hazard of the particles. In addition, the surface area is also an important physico-chemical parameter of particles. Our Brunauer-Emmett-Teller (BET) data indicated that the $\mathrm{SiO}_{2}$ particles have a larger surface area $\left(537.8 \mathrm{~m}^{2} / \mathrm{g}\right)$ than the $\mathrm{Fe}_{3} \mathrm{O}_{4}$ particles (Figure 1C). The aforementioned characteristics would help us to better analyze the biocompatibility and toxicity properties of the particles.

\section{Cytotoxicity of the particles}

In this study, THP-1 cells and HUVECs were used to investigate the biological effects of $\mathrm{SiO}_{2}$ or $\mathrm{Fe}_{3} \mathrm{O}_{4}$ particles. Monocytes are involved in the first line of defense in the immune system and protect the body as a scavenger of foreign agents via phagocytosis. As a result, evaluating nanotoxicity using these two cell types can provide a comprehensive immuno-inflammatory nanotoxicity assessment of particles. Generally, the performance of cell viability assays is a basic step in nanotoxicology that demonstrates the cellular response to particles. Herein, the cytotoxicity of $\mathrm{SiO}_{2}$ or $\mathrm{Fe}_{3} \mathrm{O}_{4}$ particles in HUVECs and THP-1 cells was measured by the MTS method, a

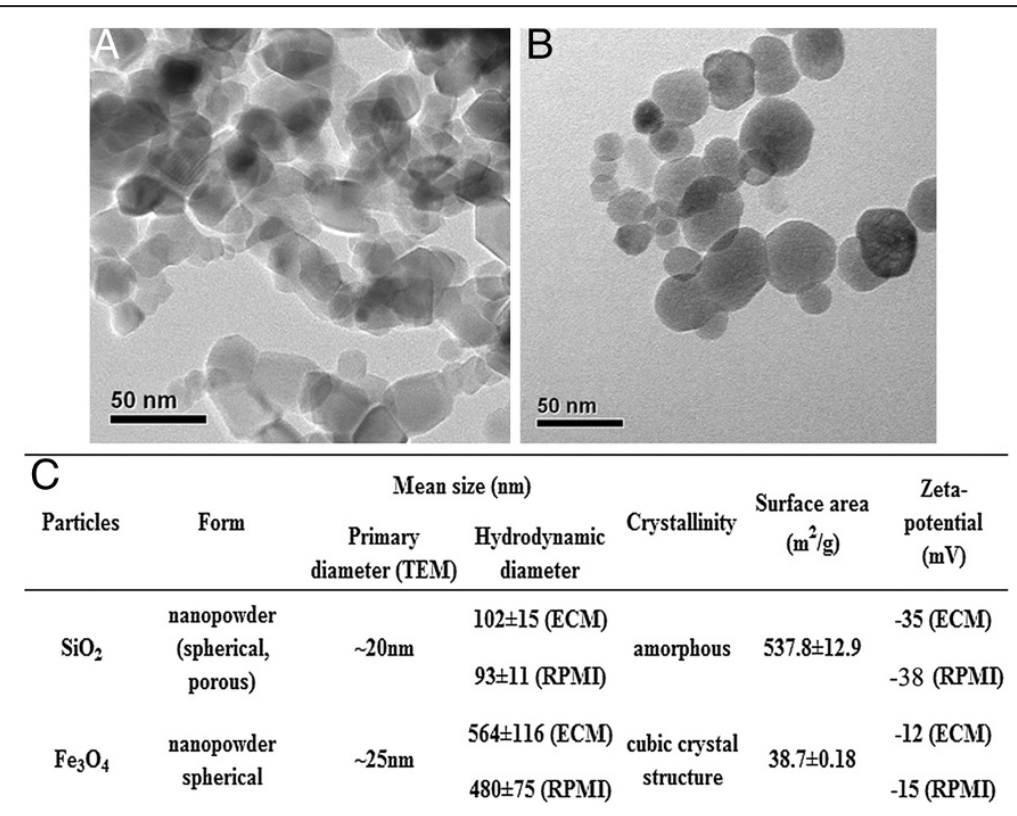

Figure 1 Characterization and cytotoxicity of the particles. A-B): TEM analysis of particles. C): Particle size, hydrodynamic diameter, surface area and zeta potential. 
type of mitochondrial succinate dehydrogenase assay. Several previous studies have shown that reagents from the MTT or LDH assays can bind to particles and produce invalid results due to particle/dye interactions or the adsorption of the dye or dye products [22,23]. However, in contrast to MTT or LDH, the MTS indicator dye is water soluble and stable in the culture medium, and it could only minimally interact with the particles. Therefore, we chose to use the MTS assay to assess the cytotoxicity of the particles. In HUVECs, a dosedependent toxic effect was observed after exposure to $\mathrm{SiO}_{2}$ or $\mathrm{Fe}_{3} \mathrm{O}_{4}$ particles at concentrations ranging from 100 to $400 \mu \mathrm{g} / \mathrm{mL}$. Exposure to $\mathrm{SiO}_{2}$ or $\mathrm{Fe}_{3} \mathrm{O}_{4}$ particles at concentrations of $200 \mu \mathrm{g} / \mathrm{mL}$ and above caused significant cytotoxic effects (Figure 2A). The cell types differed in viability; in THP-1 cells, no significant loss of viability was observed at any of the concentrations tested (Figure 2B).

\section{Particle uptake}

Phagocytosis is mainly conducted by specialized mammalian cells, such as macrophages, monocytes and neutrophils $[15,24]$. In nonphagocytic cells, there are three major endocytic pathways: macropinocytosis, clathrinmediated endocytosis, and caveolin-dependent endocytosis $[24,25]$. The plasma membrane protrusion for cellular uptake is one of the characteristics of phagocytosis [15]. As depicted in Figure 3, our results showed that multiple pseudopodia of plasma membrane were formed for the uptake of the $\mathrm{SiO}_{2}$ or $\mathrm{Fe}_{3} \mathrm{O}_{4}$ particles in monocytes but not HUVECs, indicating that $\mathrm{SiO}_{2}$ or $\mathrm{Fe}_{3} \mathrm{O}_{4}$ particles might enter into monocytes via phagocytosis and into ECs via other endocytic pathways. Moreover, in both cell types, most particles were observed to sequester in vesicles and lysosomes; however, there was no evidence of particles entering nuclei and mitochondria, suggesting that the final destination of transported $\mathrm{SiO}_{2}$ or $\mathrm{Fe}_{3} \mathrm{O}_{4}$ particles is the lysosomes. The results are consistent with other studies that showed that particles are preferentially localized in the lysosomes of HeLa cells and human breast-cancer cells $[26,27]$. Notably, in THP-1 cells, despite the fact that the lysosomes engulfed large numbers of particles, the morphology did not change significantly, and the structure remained homogeneous. In contrast, with the accumulation of particles in HUVECs, the size of the lysosomes significantly increased, while the structure and morphology became irregular and indicative of cellular perturbation by events within lysosomes. Lysosomal perturbation might be a major mechanism for particle cytotoxicity and explain why HUVECs are more susceptible to particles than monocytes. Because the subsequent experiments required functioning and metabolically active cells, a low dose $(100 \mu \mathrm{g} / \mathrm{mL})$ that did not significantly affect the viability of monocytes or ECs was used in this study.

\section{Monocytes amplify particle-induced endothelial cell inflammatory responses}

Previous studies have examined the effects of particles on both HUVEC and THP-1 cells in monocultures, whereas the effects of particles on cell-cell interactions have not been investigated in detail. In the present study, we established a coculture model that permits direct communication and the interaction of monocytes with ECs to assess the potential proinflammatory and prothrombotic risks of $\mathrm{SiO}_{2}$ or $\mathrm{Fe}_{3} \mathrm{O}_{4}$ particles. Prior to investigating monocyte-EC interactions, the purity of HUVECs and THP-1 cells was assessed by flow cytometry. Our data showed that the purity of monocytes or HUVECs isolated from a silica particle-treated coculture was slightly lower than that of monocytes or HUVECs
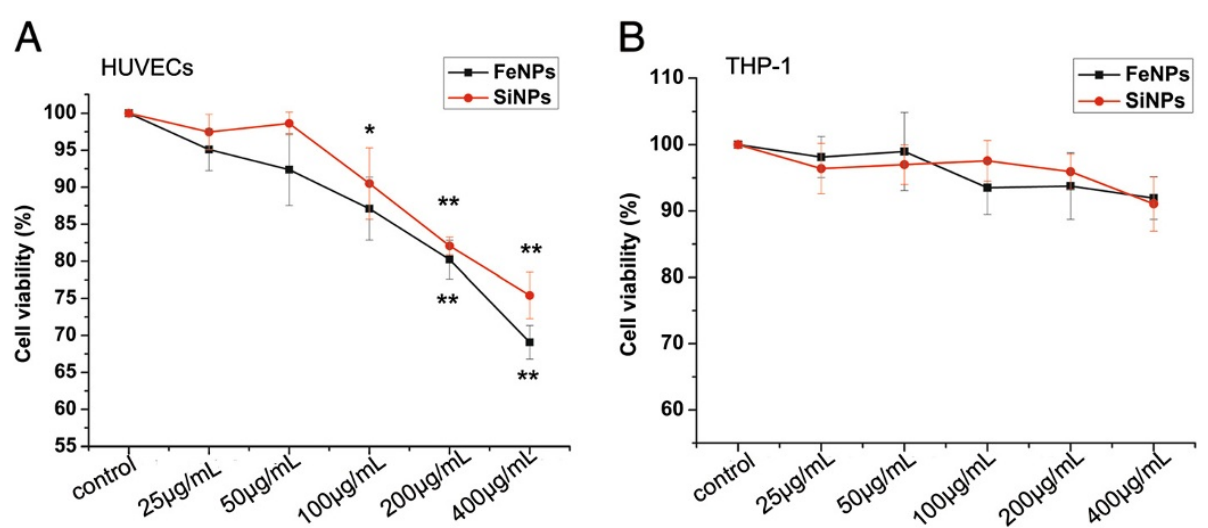

Figure 2 Cytotoxicity of the particles to HUVECs and THP-1 cells. A): HUVECs and B): THP-1 cells. Cells were exposed to increasing doses of particles for $24 \mathrm{~h}$, and the cytotoxicity was determined by the MTS assay. Normal HUVECs or THP-1 cells without particle treatment served as controls. The results are presented as the mean \pm SEM of three independent experiments, each of which was carried out in triplicate. ${ }^{*} p<0.05$, ${ }^{* *} \mathrm{p}<0.01$ vs. control. (FeNPs: $\mathrm{Fe}_{3} \mathrm{O}_{4}$ particles; $\mathrm{SiNPs}_{\mathrm{S}} \mathrm{SiO}_{2}$ particles). 


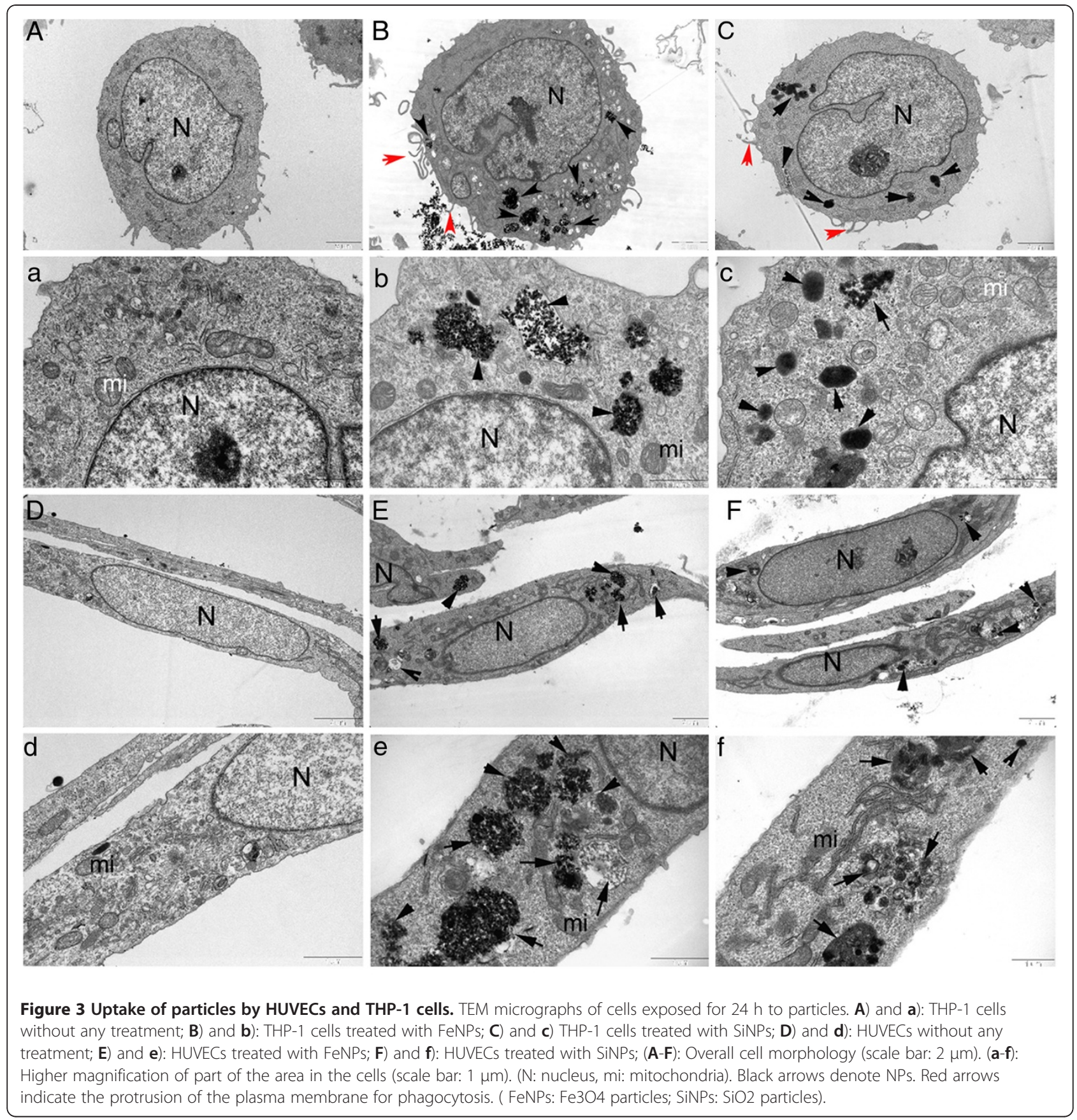

isolated from an untreated coculture, suggesting that the particles may elicit the attachment of monocytes to HUVECs. However, the low level of contamination with the other cell type after separation from cocultures $(<10 \%)$ would not likely affect the measurements (Figure 4). Endothelial cell activation, a proinflammatory and procoagulant state of the ECs, is characterized by the upregulation of adhesion molecule expression, including VCAM-1 (CD106), ICAM-1 (CD54) and Eselectin (CD62E) [28]. Thus, in our initial experiments, we used particles to stimulate the coculture system and examined the expression of CD54, CD106 and CD62E in HUVECs. As illustrated in Figure 5, untreated quiescent HUVECs express constitutive levels of surface CD54 but no detectable CD106 or CD62E. In a monoculture of HUVECs, only CD62E expression was slightly upregulated by $\mathrm{SiO}_{2}$ particles. It was unexpected that when HUVECs were cocultured with THP-1 cells, both CD106 and CD62E expression were markedly increased upon exposure to the $\mathrm{SiO}_{2}$ particles compared with the HUVEC monoculture stimulated with $\mathrm{SiO}_{2}$ particles, while no change in CD54 expression was observed. Both 

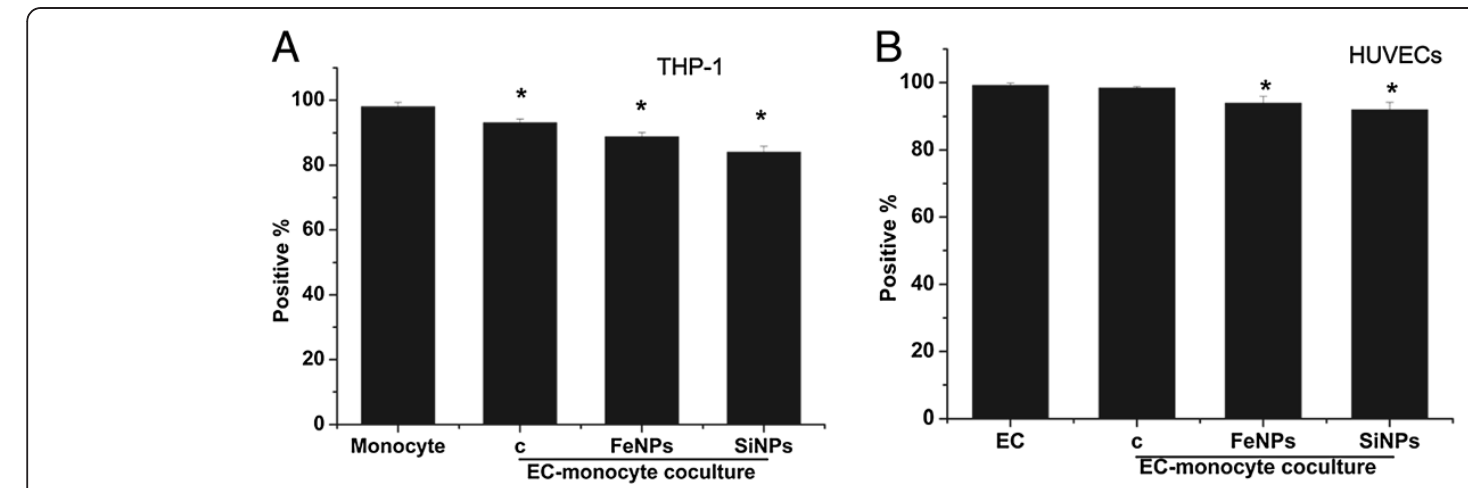

Figure 4 The purity of HUVECs and THP-1 cells from cocultures. The bar graph shows $\mathbf{A}$ ): CD11a positive THP-1 cells and $\mathbf{B}$ ): $v W F$ positive HUVECs. Data represent the means $\pm \mathrm{SEM} ; \mathrm{n}=3$. ${ }^{*} \mathrm{p}<0.05$ vs. control. (c: control, FeNPs: $\mathrm{Fe}_{3} \mathrm{O}_{4}$ particles; $\mathrm{SiNPs}_{\mathrm{S}} \mathrm{SiO}_{2}$ particles, EC: endothelial cells).

CD106 and CD62E play an important role in recruiting monocytes and mediating monocyte rolling and adhesion to the internal surface of the blood vessel. In addition to upregulating adhesion molecules, ECs react to stimuli by secreting various proinflammatory cytokines and chemokines, including interleukin (IL)-8, IL-6 and monocyte chemoattractant protein (MCP)-1. Our results also indicate that $\mathrm{SiO}_{2}$ particles significantly upregulated the production of IL-6, IL-8, and MCP-1 in a monocyte/ HUVEC co-culture system, compared with HUVECs alone cultured with $\mathrm{SiO}_{2}$ particles. Because THP-1 cells alone cultured with $\mathrm{SiO}_{2}$ particles did not elicit detectable IL-6, IL-8, and MCP-1 responses (Figures 6A-C), the results indicate that $\mathrm{SiO}_{2}$-particle-induced cell-cell interactions led to an increased IL-6, IL-8, and MCP-1 production by ECs. IL- 6 has been shown to increase

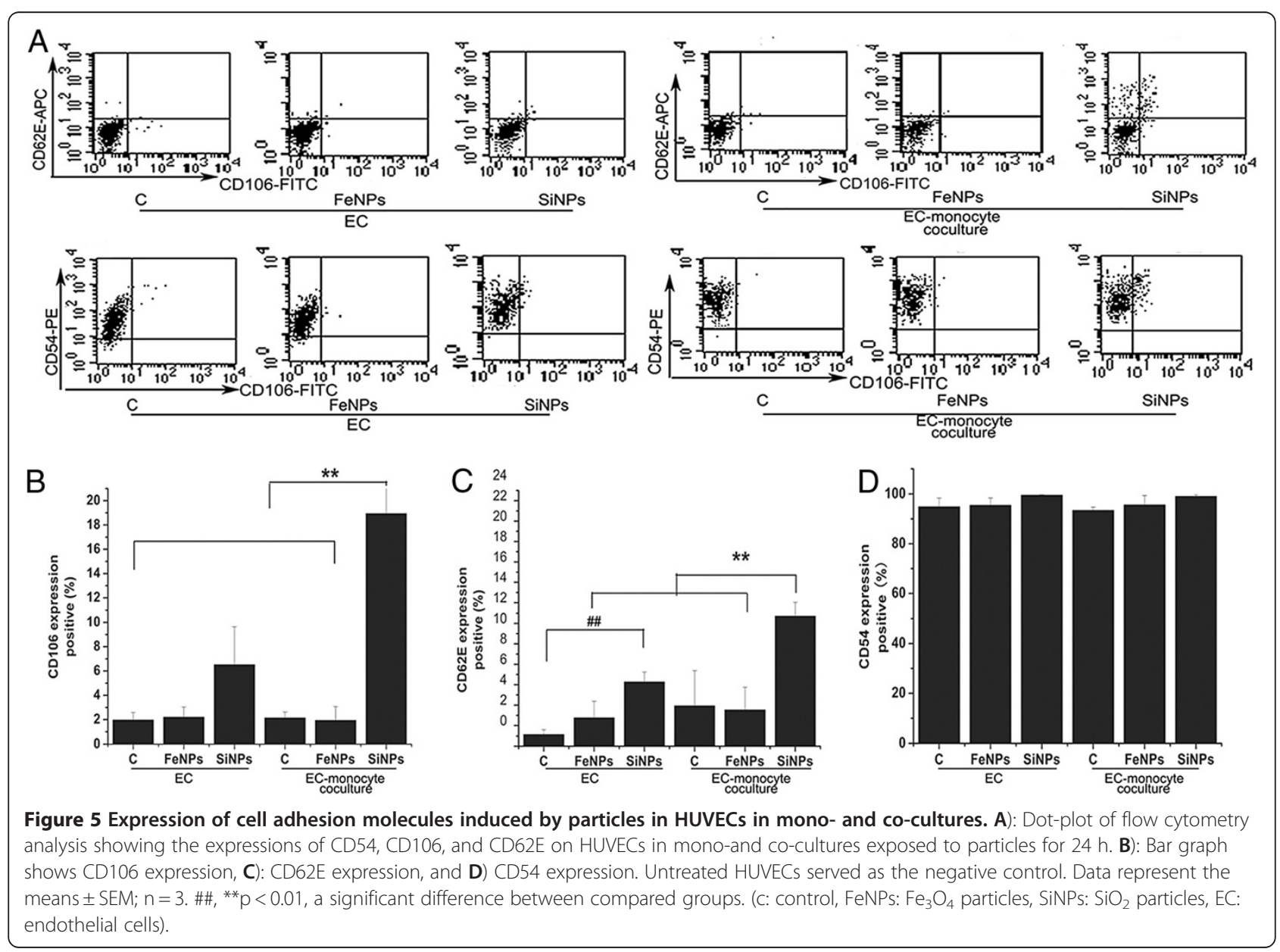



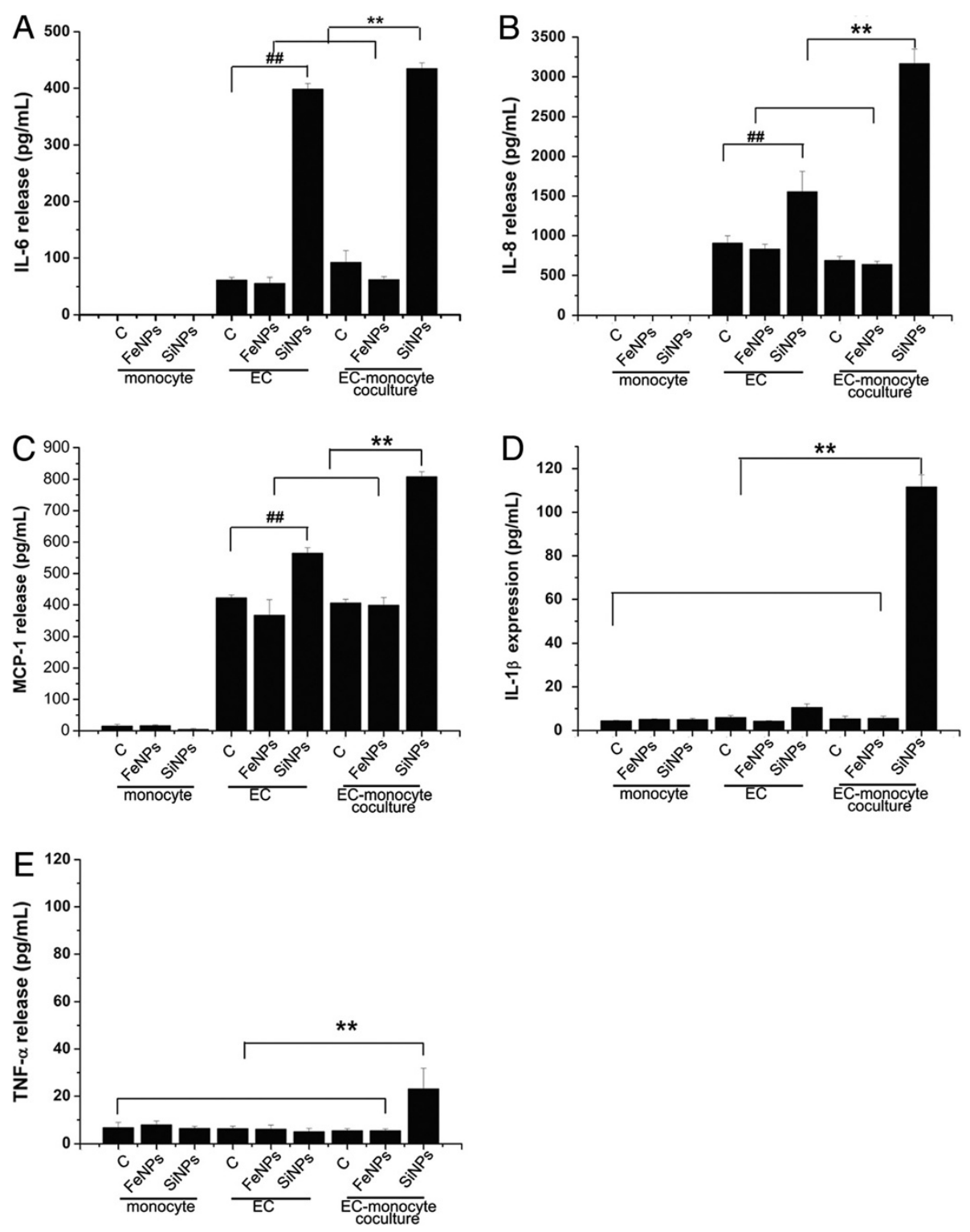

Figure 6 Cytokine production induced by particles in mono- and co-cultures. A): IL-6 release; B): IL-8 release; C): MCP-1 release; D): IL-1 $\beta$ release; E): TNF-a release. Untreated HUVECs or THP-1 cells served as negative controls. Data represent the mean $\pm S D, n=3$. \#\# $p<0.01$, ${ }^{* *} \mathrm{p}<0.01$, a significant difference between compared groups. (c: control, FeNPs: $\mathrm{Fe}_{3} \mathrm{O}_{4}$ particles; $\mathrm{SiNPs}_{\mathrm{SiO}} \mathrm{Sir}_{2}$ particles, EC: endothelial cells).

smooth muscle cell proliferation and migration and may promote atherosclerotic lesions and plaque vulnerability through the stimulation of acute-phase protein synthesis $[29,30]$. In addition, both MCP-1 and IL-8 also contribute to arteriosclerotic lesion formation and trigger firm adhesion of monocytes to the EC layer [31]. Previous studies have reported that iron oxide particles' challenge to ECs upregulates the expression of cell adhesion molecules and cytokines, promotes monocyte adhesion to ECs and contributes to the initial development of atherosclerosis [32]. In contrast, other studies have demonstrated that $\mathrm{Fe}_{2} \mathrm{O}_{3}$ NPs do not provoke an inflammatory response in endothelial cells [6]. In our studies, we found that $\mathrm{Fe}_{3} \mathrm{O}_{4}$ particles have no significant effect on endothelial cell adhesion molecule expression or cytokine release in a monoculture or cocultures. Our present data indicate the presence of a positive feedback loop that enables the adhesion of monocytes to ECs, thus contributing to the proinflammatory responses of vascular endothelium upon exposure to $\mathrm{SiO}_{2}$ particles.

\section{EC-mediated proinflammatory and procoagulant} activation of monocytes in response to $\mathrm{SiO}_{2}$ particles Having shown that monocyte-endothelial cell interactions can enhance the endothelial inflammatory response to $\mathrm{SiO}_{2}$ particles, we analyzed monocyte activation to 
test whether this phenomenon is restricted to ECs. TNF- $\alpha$ and IL-1 $\beta$ were used as markers of monocyte activation. Notably, neither HUVECs nor monocytes produced TNF- $\alpha$ or IL-1 $\beta$ with $\mathrm{SiO}_{2}$-particle treatment. However, a massive amplification of TNF- $\alpha$ ( $\sim$-fold $)$ and IL-1 $\beta(\sim 10$-fold) secretion was observed in response to $\mathrm{SiO}_{2}$ particles, but not $\mathrm{Fe}_{3} \mathrm{O}_{4}$ particles, in the monocyte/EC coculture compared with THP-1 cells or HUVECs alone stimulated with particles, suggesting that monocytes/ECs in coculture are more responsive to $\mathrm{SiO}_{2}$ particles than either cell type alone (Figures 6D-E). Many previous studies have shown that cocultures of multiple cell types have an increased sensitivity to microparticles and release more proinflammatory cytokines than one cell type alone [33-35]. It has been reported that mesoporous $\mathrm{SiO}_{2}$-particles hardly induce proinflammatory cytokines, such as TNF- $\alpha$ and IL- $1 \beta$, in macrophages [36]. However, an increased release of proinflammatory cytokines (TNF- $\alpha$ and IL-1 $\beta$ ) in blood after injection with $\mathrm{SiO}_{2}$ particles has previously been observed in vivo [37]. Taken together with our results, it is likely that $\mathrm{SiO}_{2}$ particles can indirectly activate monocytes through the stimulation of ECs.

An important mechanism whereby vascular inflammation can contribute to thrombosis is through the upregulation of tissue factor (TF) expression [38], which results in the activation of the extrinsic blood coagulation cascade. Monocytes have been recognized as the main cell type that can be induced to synthesize TF de novo. Therefore, we subsequently investigated the expression of TF by THP-1 cells in monoculture and cocultures exposed to particles. Figure 7 shows that THP-1 cells alone did not exhibit any increase in the expression of TF after exposure to $\mathrm{SiO}_{2}$ or $\mathrm{Fe}_{3} \mathrm{O}_{4}$ particles. Another group has also reported that synthetic amorphous $\mathrm{SiO}_{2}$ particles had virtually no effect on TF gene transcription in monocytes [39]. However, in the present study, THP-1 cells cocultured with HUVECs exhibited a significant increase in TF expression in response to $\mathrm{SiO}_{2}$ particles, while $\mathrm{Fe}_{3} \mathrm{O}_{4}$ particles did not induce TF expression in THP-1 cells in cocultures. Data generated by these experiments suggest that even though $\mathrm{SiO}_{2}$ particles have no proinflammatory or procoagulant activity on ECs or monocytes alone, their proinflammatory and procoagulant potential can be dramatically induced and augmented by particle-induced monocyte-endothelial cell interactions.

\section{Soluble factors and cell-to-cell contact-dependent mechanisms}

In the next step, we investigated whether soluble factors from $\mathrm{SiO}_{2}$-particle-stimulated monocytes are responsible for EC activation. Thus, cell-free supernatants of monocytes activated with $\mathrm{SiO}_{2}$-particles were used to stimulate HUVECs. Interestingly, although cocultures activated with $\mathrm{SiO}_{2}$ particles resulted in the dramatic enhancement of EC activation, the supernatant of $\mathrm{SiO}_{2}$-particle-stimulated monocytes did not upregulate CAMs expression or the release of cytokines in HUVECs (Figures 8A-B), suggesting that direct cell-cell contact of HUVECs with THP-1 cells is a key determinant for amplified CAMs and cytokine expression in the $\mathrm{SiO}_{2}$-particle-stimulated cocultures. Subsequently, we also used cell-free supernatants of $\mathrm{SiO}_{2}$-particle-activated HUVECs to stimulate THP-1 cells. Similarly, the supernatant of $\mathrm{SiO}_{2}$-particle-stimulated HUVECs had no impact on TNF- $\alpha$ or IL- $1 \beta$ production, suggesting that monocyte activation in $\mathrm{SiO}_{2}$-particle-stimulated cocultures also requires direct cell-to-cell contact (Figure 8C). In contrast, the supernatant of $\mathrm{SiO}_{2}$-particlestimulated HUVECs was capable of markedly increasing TF expression in THP-1 cells $(80.29 \pm 2.76 \%)$ (Figure 8D); there was no significant difference compared with TF expression in THP-1 cells $(82.03 \pm 2.56 \%)$ in $\mathrm{SiO}_{2}$-particleactivated cocultures (Figure 7 ), indicating that soluble
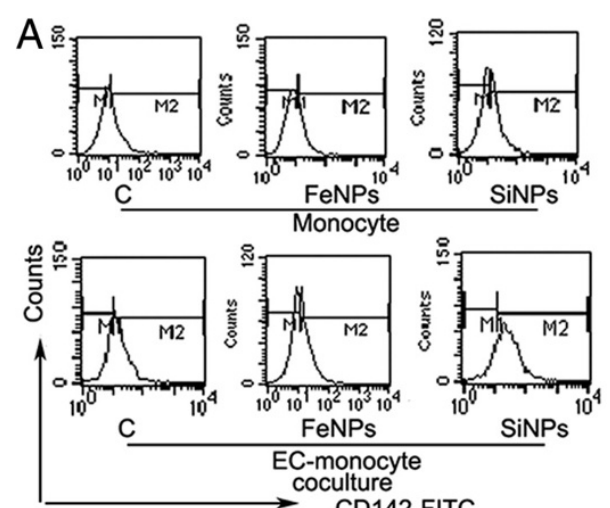

CD142-FITC

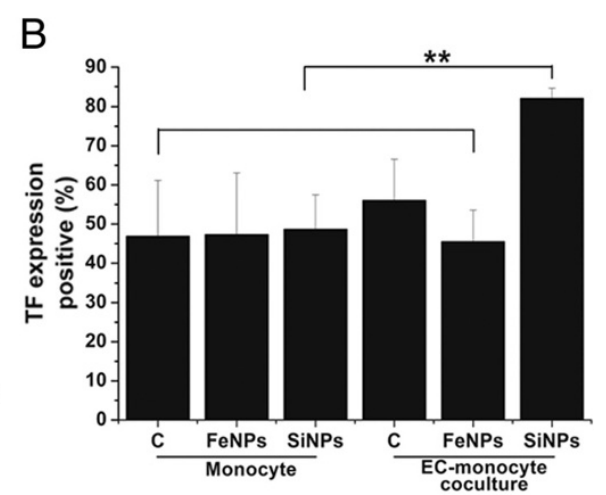

Figure 7 The effect of particles on tissue factor (TF) expression in THP-1 cells in mono- and co-cultures. A): TF expression is depicted by a histogram of flow cytometry analysis. B): The bar graph shows the percentage of TF positive cells. Data represent the means \pm SEM; $n=3$. ${ }^{* *} \mathrm{p}<0.01$, a significant difference between compared groups. (c: control, FeNPs: $\mathrm{Fe}_{3} \mathrm{O}_{4}$ particles; $\mathrm{SiNPs}_{\mathrm{N}} \mathrm{SiO} 2 \mathrm{particles,} \mathrm{EC:} \mathrm{endothelial} \mathrm{cells).}$ 

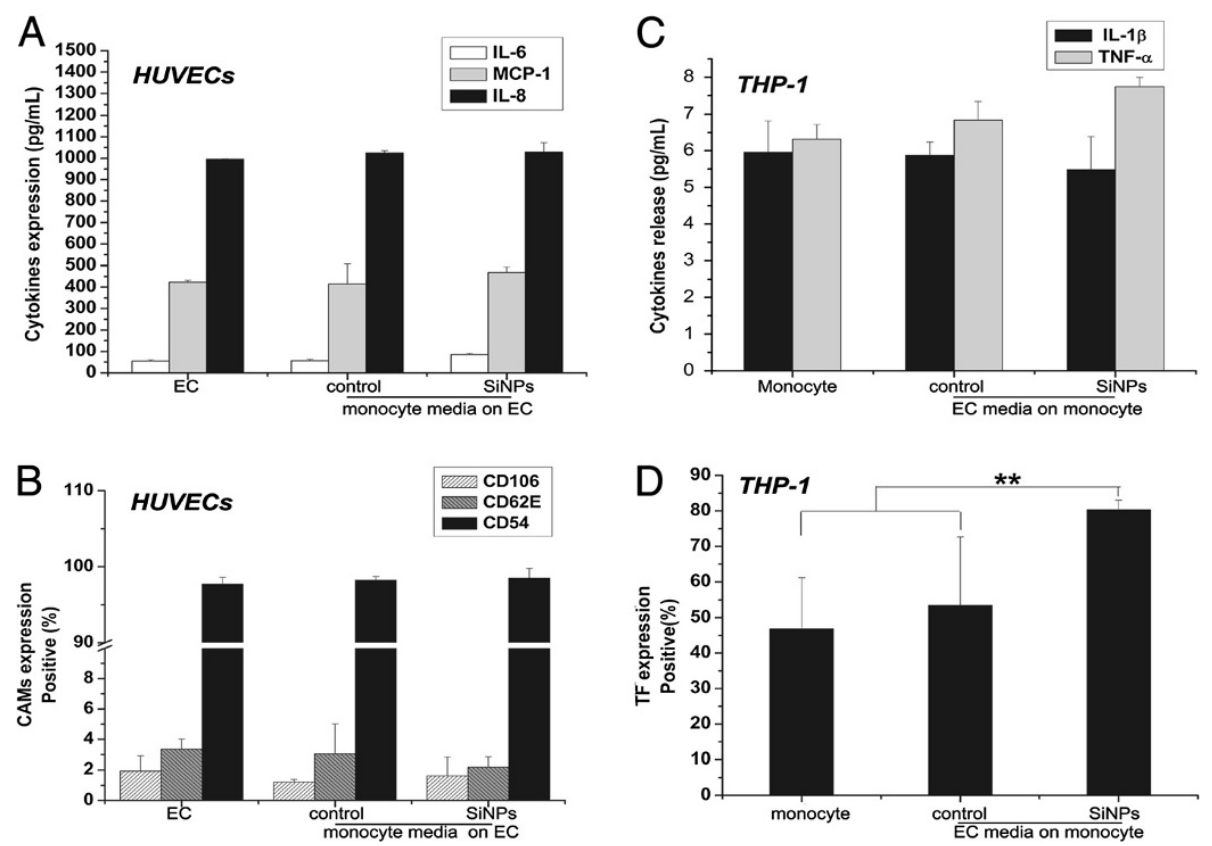

Figure 8 The expression of cytokines, CAMs and TF in HUVECs and THP-1 cells treated with the supernatants of $\mathrm{SiO}_{2}$-particlestimulated cells. A): IL-6, IL-8 and MCP-1 release; B): Expression of cell adhesion molecules (CAMs) in HUVECs treated by the supernatants of $\mathrm{SiO}_{2}$-particle-stimulated THP-1 cells; C): TNF-a and IL-1 $\beta$ release; D) TF expression in THP-1 cells treated by the supernatants of $\mathrm{SiO}_{2}$-particle-stimulated HUVECs. Data represent the means $\pm \mathrm{SEM} ; \mathrm{n}=3$. ${ }^{* *} \mathrm{p}<0.01$, a significant difference between compared groups. (SiNPs: $\mathrm{SiO}_{2}$ particles, EC: endothelial cells).

factors from activated ECs may significantly contribute to TF expression in monocytes in cocultures activated with $\mathrm{SiO}_{2}$ particles. It was attributed to higher IL-6 and IL-8 levels in the supernatant of $\mathrm{SiO}_{2}$-particle-stimulated HUVECs because IL- 6 and IL-8 have been reported to induce an increase in the surface expression of TF in monocytes [40].

In contrast with soluble factors, the role of direct cellto-cell contact in amplifying biological effects in particlestimulated coculture systems has received little attention. A previous study has found that supernatants from macrophages strongly induce adhesion molecule expression on ECs [41]. However, our findings suggest that direct cell-to-cell contact is a prerequisite for enhanced cytokine generation (IL-6, IL-8, MCP-1, TNF- $\alpha$, and IL$1 \beta)$ and CAMs expression in $\mathrm{SiO}_{2}$-particle-stimulated cocultures. In general, upon cell-to-cell contact and ligand-receptor engagement, intracellular signaling is induced in a bidirectional manner. CD40 is a member of the tumor necrosis factor receptor (TNF-R) superfamily that is activated by ligand of CD 40 (CD40L), a member of the TNF- $\alpha$ family. CD40 and CD40L were originally known as co-stimulatory molecules that are indispensable for the function of antigen-presenting cells and activated $\mathrm{CD}^{+} \mathrm{T}$ cells. Recent studies found that CD40-CD40L interactions between ECs and monocytes can significantly increase CAMs expression in ECs or
IL-1 $\beta$ release from monocytes [12,42]. Thus, to further investigate the possible cell-to-cell contact-dependent signaling mechanism, CD40 and CD40L expression in monocytes and ECs were analyzed after exposure to $\mathrm{SiO}_{2}$ particles. As shown in Figure 9, CD40L expression in HUVECs was strongly induced by $\mathrm{SiO}_{2}$ particles. In contrast, exposure to $\mathrm{SiO}_{2}$ particles had no effect on CD40 expression in HUVECs; similar results were also observed in THP-1 cells exposed to $\mathrm{SiO}_{2}$ particles (Figure 9). As reported in a previous study, CD40L synthesis in HUVECs was likely dependent on a redoxsensitive mechanism [13].

\section{Activation of the ROS, MAPK and NF-KB pathways}

Subsequently, ROS production was monitored by flow cytometry with 2/,7/-dichlorodihydrofluorescein diacetate (DCFH-DA), which is the most widely used probe for detecting intracellular oxidative stress. Moreover, DCFH-DA has also been used as an indicator for the mitochondrial generation of oxidants and peroxynitrite in endothelial cells [43]. As shown in Figure 10, after $24 \mathrm{~h}$, intracellular ROS in HUVECs were significantly induced by $\mathrm{SiO}_{2}$ particles; however, in THP-1 cells, $\mathrm{SiO}_{2}$ particles failed to increase intracellular ROS levels. Oxidative stress is one of the most important toxicological paradigms and mechanisms for the toxicity of engineered particles [44,45]. Our previous studies have 

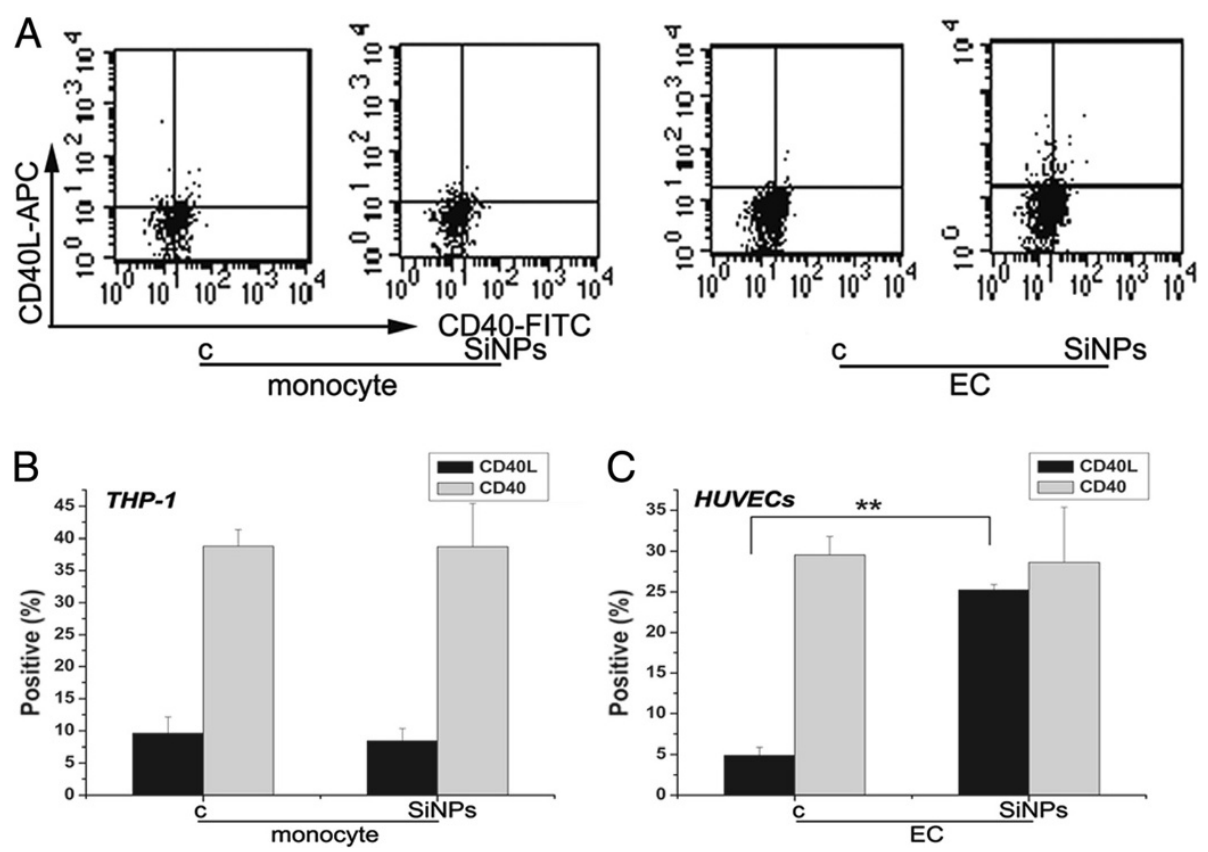

Figure $9 \mathrm{CD} 40 \mathrm{~L}$ and $\mathrm{CD} 40$ expression induced by $\mathrm{SiO}_{2}$ particles in HUVECs and THP-1 cells. A): Dot-plot of flow cytometry analysis showing the expressions of CD4OL and CD40 on THP-1 cells and HUVECs; B): The bar graph shows the percentage of CD40L or CD40 positive THP-1 cells; C): The bar graph shows the percentage of CD40L or CD40 positive HUVECs. Untreated HUVECs or THP-1 cells served as controls. Data represent the mean $\pm \mathrm{SEM}, \mathrm{n}=3 .{ }^{* *} \mathrm{p}<0.01$ vs. control. (c: control, SiNPs: $\mathrm{SiO}_{2}$ particles, EC: endothelial cells).

shown that $\mathrm{SiO}_{2}$ particles exerted the toxic effects of oxidative stress in HUVECs and PC12 cells $[8,46]$, the current study further found that ROS generation was significantly enhanced or induced by monocyteendothelial cell interactions (Figures 10A-B). To further clarify the possible signaling pathways underlying $\mathrm{SiO}_{2}$ particle-induced monocyte-endothelial cell interactions, the activation of c-Jun NH2-terminal kinase (JNK), p38 MAP kinase and NF- $k B$ was analyzed in THP-1 cells and HUVECs in mono- and co-cultures stimulated with $\mathrm{SiO}_{2}$ particles. MAPK represents an intracellular signaling pathway that processes a wide variety of stimuli, including environmental stresses and cytokines, through ERK, JNK and p38 [47]. Among these signaling peptides, p38 MAPK is considered the central regulator of inflammation, and JNK is also involved in inflammatory responses. Furthermore, NF- $\mathrm{kB}$ plays a central role in the development of inflammation through the regulation of genes encoding not only pro-inflammatory cytokines but also adhesion molecules, such as E-selectin, VCAM1 and ICAM-1, chemokines and TF. Our previous study showed that $\mathrm{SiO}_{2}$ particles can activate JNK and NF-kB through oxidative stress in HUVECs [8]. The present study further found that the stimulation of cocultures with $\mathrm{SiO}_{2}$ particles strongly enhances JNK phosphorylation and NF- $\mathrm{KB}$ activation in both HUVECs and THP-1 cells, whereas p38 phosphorylation was not affected by $\mathrm{SiO}_{2}$-particles in either the monocultures or cocultures
(Figure 10). Previous studies have reported that CD40LCD40 signaling can stimulate inflammation in an Akt, p38/JNK MAP kinase, and NF- $\mathrm{kB}$ dependent manner $[12,13]$. Thus, it is likely that the enhanced NF- $\mathrm{KB}$ and JNK activity in THP-1 cells and HUVECs in $\mathrm{SiO}_{2}$-particle-stimulated cocultures is due to CD40-CD40L interactions.

Taken together, our results indicate that $\mathrm{SiO}_{2}$ particles may induce CAMs, chemokines and receptor/ligand expression in ECs resulting in the preferential recruitment of monocytes from blood and their adhesion to ECs. The interaction of monocytes with ECs (via the CD40-CD40L pathway) results in the activation of both ECs and monocytes, which then release more proinflammatory cytokines or chemokines and induce the increased expression of CAMs or TF. Thus, a positive feedback loop may be created that could finally lead to cardiovascular dysfunction.

\section{Conclusion}

In summary, an in vitro model system of endothelial cell and monocyte coculture was developed that mimics cell communication within the bloodstream and could lead to a better understanding of the different cellular mechanisms related to the responses after exposure to inorganic particles. Our results indicated that the production of proinflammatory cytokines and chemokines and the expression of CD106, CD62E and TF are significantly 

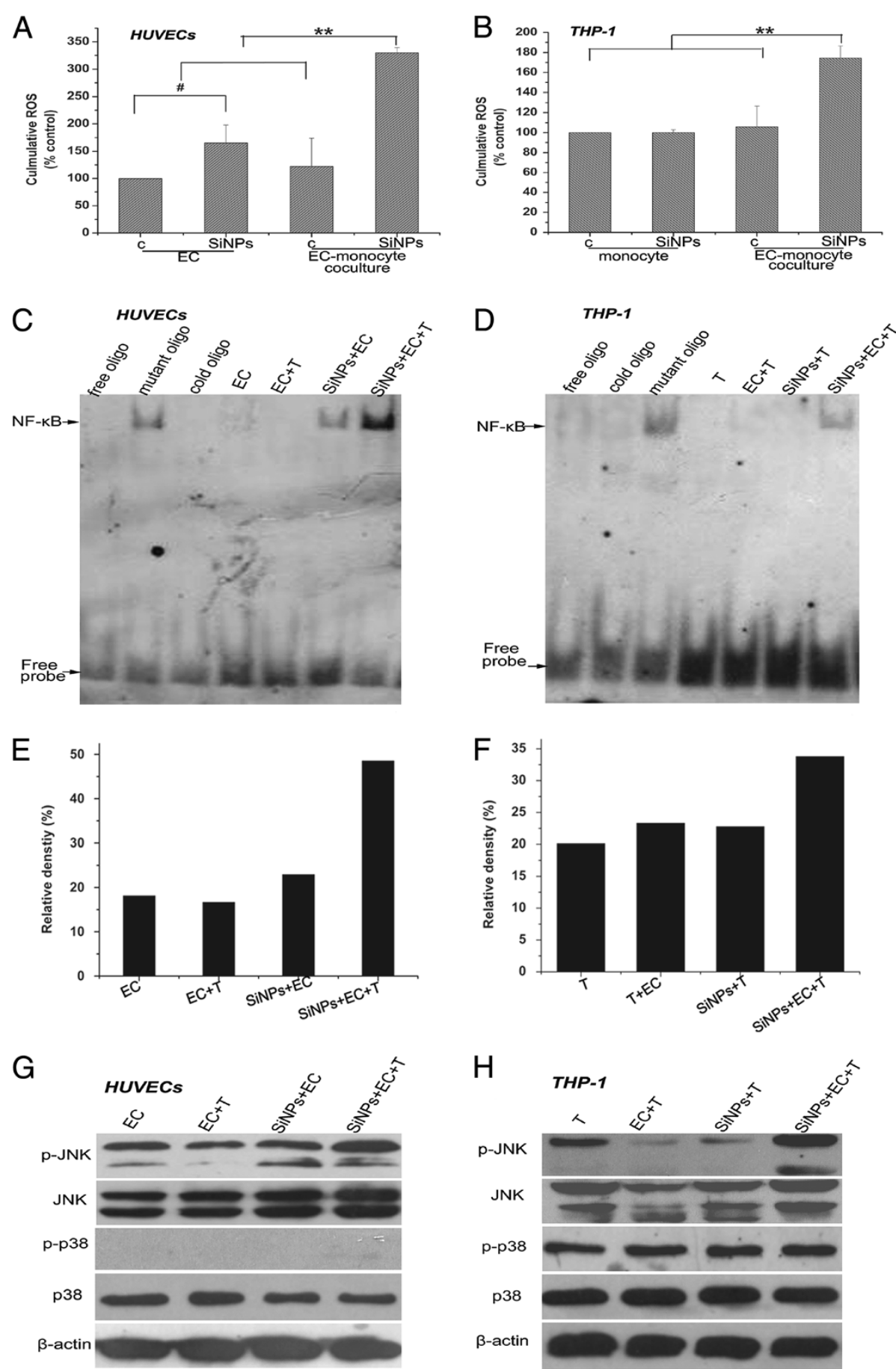

Figure 10 ROS generation and NF-KB, JNK and p38 activation by $\mathrm{SiO}_{2}$ particles in HUVECs and THP-1 cells in mono- and co-cultures. A, B): ROS generation by $\mathrm{SiO}_{2}$ particles in HUVECs and THP-1 cells in mono- and co-cultures. C, D): The activation of NF- $\mathrm{KB}$ by $\mathrm{SiO}_{2}$ particles in HUVECs and THP-1 cells in mono- and co-cultures. NF-KB DNA-binding activity was assayed by the electrophoretic mobility shift assay (EMSA) as described in the Methods section. The detection of band specificity of NF-KB activation was measured with unlabeled oligo-, cold and mutated NF-kB oligonucleotides. E, F): The relative density of the bands from EMSA by gray value analysis. G, $\mathbf{H}$ ): The activation of $\mathrm{JNK}$ and $\mathrm{p} 38$ by $\mathrm{SiO}_{2}$ particles in HUVECs and THP-1 cells in mono- and co-cultures. Aliquots of the cell lysates were separated by SDS-PAGE and analyzed for protein expression by Western blotting, as described in the Methods section. $\beta$-actin was used as an internal control to monitor for equal loading. Data represent the means $\pm \mathrm{SEM} ; \mathrm{n}=3$. $\# \mathrm{p}<0.05,{ }^{* *} \mathrm{p}<0.01$, a significant difference between compared groups. (c: control, $\mathrm{SiNPs}_{\mathrm{N}} \mathrm{SiO}_{2} \mathrm{particles,} \mathrm{EC}$ : endothelial cells, T: THP-1 cells). 
enhanced to a greater degree in $\mathrm{SiO}_{2}$-particle-activated cocultures than in the individual cell types alone, suggesting that the co-cultures represent a sensitive in vitro model system in which to assess the potency of particles and illustrate that the safe application of nanomaterials requires the evaluation of both the direct and indirect proinflammatory and procoagulant potential of particles. Furthermore, our data also demonstrate that $\mathrm{SiO}_{2}$ particles can significantly augment proinflammatory and procoagulant responses through CD40-CD40L-mediated monocyte-endothelial cell interactions via the JNK/NF- $\mathrm{kB}$ pathway, suggesting that cooperative interactions between particles, ECs, and monocytes may trigger or exacerbate cardiovascular dysfunction and disease, such as atherosclerosis and thrombosis. The findings provide important information that may help guide the future design and use of inorganic particles in biomedical applications.

\section{Methods}

\section{Preparation and characterization of $\mathrm{SiO}_{2}$ particles and $\mathrm{Fe}_{3} \mathrm{O}_{4}$ particles}

$\mathrm{SiO}_{2}$ [Cat. No: 637246] and $\mathrm{Fe}_{3} \mathrm{O}_{4}$ particles [Cat. No: 637106] were purchased from Sigma-Aldrich (Sigma, St. Louis, MO, USA). The size and shape of these particles were examined under a transmission electron microscope (TEM) (JEOL, Tokyo, Japan). The specific surface area of these samples was determined by the BrunauerEmmett-Teller (BET) method using a Surface Area Analyzer (ASAP2020, Micromeretics, GA, USA) after pre-preparation of the samples by heating them at $200^{\circ} \mathrm{C}$ in a stream of $\mathrm{N}_{2}$ in excess of $24 \mathrm{~h}$. The hydrodynamic diameter of these particles in endothelial cell medium (ECM) (Sciencell, San Diego, USA) and RPMI 1640 medium (GIBCO, Scotland, UK) was measured with a Malvern Zetasizer instrument (Malvern Instruments, Worcestershire, UK). In the present study, before inoculation into the in vitro systems, these particles were sterilized by ethylene oxide, and the amount of residual styrene oxide of the particles was no more than $10 \mu \mathrm{g} / \mathrm{g}$. A series of particle concentrations ranging from $25 \mu \mathrm{g} /$ $\mathrm{mL}$ to $400 \mu \mathrm{g} / \mathrm{mL}$ was chosen to test the potential effects of the particles on HUVECs or THP-1 cells. The final particle dispersions were prepared freshly before use by serial dilution of the stock suspension $(1 \mathrm{mg} / \mathrm{mL})$ in ECM or RPMI 1640 medium (GIBCO, Scotland, UK), followed by intense vortexing. The endotoxin content of the samples was negative at the level of $1 \mathrm{EU} / \mathrm{mL}$.

\section{Cell preparation and culture}

HUVECs were isolated and cultured using a modification of the method described by Jaffe [48]. Briefly, the umbilical vein was rinsed three times with phosphatebuffered saline (PBS) containing $100 \mathrm{U} / \mathrm{mL}$ penicillin/ streptomycin (GIBCO, Scotland, UK), filled with $0.1 \%$ collagenase I (Sigma, St. Louis, MO, USA), and incubated at $37^{\circ} \mathrm{C}$ for $15 \mathrm{~min}$. Subsequently, the cells were collected by perfusion with $\mathrm{PBS}$ and centrifuged at $1,000 \mathrm{rpm}$ for $10 \mathrm{~min}$. After being harvested, the ECs were placed in $75-\mathrm{cm}^{2}$ tissue culture flasks (Corning, US) and grown in ECM. HUVECs between the third and sixth passages were used in our experiments. The phenotype of the ECs was confirmed by performing immunofluorescence with monoclonal antibodies for the von Willebrand factor (Changdao Biotech, China). Human monocytes (THP-1) were purchased from the Cell Bank of Chinese Academy of Sciences (Shanghai, China) and cultured in RPMI 1640 medium with 10\% fetal bovine serum (FBS) (BiochromAG, Berlin, Germany) and $100 \mathrm{U} / \mathrm{mL}$ penicillin/streptomycin.

For contact coculture of monocytes and HUVECs, $2 \mathrm{~mL}$ aliquots of THP- 1 cells $\left(1 \times 10^{6}\right.$ cells/well $)$ were added to 6-well plates onto confluent HUVEC layers $\left(5 \times 10^{5}\right.$ cells/well) in ECM. Experiments with contact cocultures were performed in the presence or absence of $\mathrm{SiO}_{2}$ particles for $24 \mathrm{~h}$. To determine the role of soluble factors in monocyte-endothelial cell interactions, THP-1 cells $\left(1 \times 10^{6}\right.$ cells $\left./ \mathrm{mL}\right)$ were treated with $\mathrm{SiO}_{2}$ particles for $24 \mathrm{~h}$; the cell-free supernatant was then harvested and transferred to stimulate the HUVECs for $24 \mathrm{~h}$. Likewise, HUVECs $\left(5 \times 10^{5}\right.$ cells $\left./ \mathrm{mL}\right)$ were treated with the particles for $24 \mathrm{~h}$, and the cell-free supernatant was transferred to stimulate the THP-1 cells for $24 \mathrm{~h}$. The purity of THP-1 cells or HUVECs separated from cocultures was assessed with cell-specific surface markers (CD11a for monocytes and von willebrand factor (vWF) for HUVECs) using flow cytometry.

\section{Cell viability assays}

To determine the toxicity levels of the particles, cell viability was measured using the MTS method, a type of mitochondrial succinate dehydrogenase assay (Cell Titer 96 Aqueous non-radioactive cell proliferation assay) (Promega, Madison, WI). HUVECs and THP-1 cell cultures were individually prepared at approximately 20,000 cells per well in 96-well plates. The monolayer of HUVECs was approximately $70-80 \%$ confluent after $24 \mathrm{~h}$. Serial dilutions of particles $(25,50,100,200$, and $400 \mu \mathrm{g} / \mathrm{mL})$ were added, and the cultures were incubated for $24 \mathrm{~h}$. Twenty milliliters of MTS was then added to each well, and the plates were incubated for $4 \mathrm{~h}$ at $37^{\circ} \mathrm{C}$ in an atmosphere of $5 \% \mathrm{CO}_{2}$ and $100 \%$ humidity. The absorbance of formazan was measured at $490 \mathrm{~nm}$ using a microplate reader (Labsystems Dragon Wellscan MK3, Finland).

\section{Particle uptake}

To determine the cellular uptake and localization of the particles, HUVECs and THP-1 cells were individually exposed to particles for $24 \mathrm{~h}$ and analyzed by electron 
microscopy. For TEM studies, HUVECs and THP-1 cells were seeded onto a 6-well plate. After incubation for $24 \mathrm{~h}$ with particles $(100 \mu \mathrm{g} / \mathrm{mL})$, the excess medium was removed, and the cells were washed with PBS solution, trypsinized and centrifuged. Then, the cell pellets were fixed in a $0.1 \mathrm{M}$ PBS solution containing $2.5 \%$ glutaraldehyde for $4 \mathrm{~h}$. The cells were dehydrated through an ethanol series (70\% for $15 \mathrm{~min}$, $90 \%$ for $15 \mathrm{~min}$, and $100 \%$ for 15 min twice) and embedded in Epon Araldite resin (polymerization at $65^{\circ} \mathrm{C}$ for $15 \mathrm{~h}$ ). Thin sections containing the cells were placed on the grids and stained for $1 \mathrm{~min}$ each with $4 \%$ uranyl acetate (in acetone: water, $1: 1$ ) and $0.2 \%$ Raynolds lead citrate (in water), air dried, and imaged under a transmission electron microscope.

\section{Intracellular ROS measurement}

The production of ROS was measured by flow cytometry using DCFH-DA (Applygen, Beijing, China). Briefly, a $10 \mathrm{mM}$ DCFH-DA stock solution (in methanol) was diluted 4,000-fold in cell culture medium without serum to yield a $2.5 \mu \mathrm{M}$ working solution. After the exposure of HUVECs or THP-1 cells to $\mathrm{SiO}_{2}$ particles $(100 \mu \mathrm{g} / \mathrm{mL})$ in cocultures or monocultures for $24 \mathrm{~h}$, the cells in 6-well plates were washed twice with PBS and incubated in $2 \mathrm{~mL}$ of the working solution of DCFH$\mathrm{DA}$ at $37^{\circ} \mathrm{C}$ in the dark for $30 \mathrm{~min}$. The cells were then washed twice with cold PBS and resuspended in PBS for the analysis of intracellular ROS with a FACScan flow cytometer (Becton Dickinson, San Jose, CA). DCFH fluorescence emission was collected with a $530 \mathrm{~nm}$ bandpass filter. The mean fluorescence intensity (MFI) of $10^{4}$ cells was quantified using Cell Quest software (Becton Dickinson, USA).

\section{Cytokine measurement}

For the analysis of cytokines (IL-6, IL-8, IL-1 $\beta$, MCP-1 and TNF- $\alpha$ ), the supernatants of HUVECs or THP-1 cells in cocultures or monocultures exposed to particles $(100 \mu \mathrm{g} / \mathrm{mL})$ were collected after $24 \mathrm{~h}$, immediately centrifuged to remove the cells, and then frozen at $-80^{\circ} \mathrm{C}$ until the analysis was performed. The amounts of IL-6, IL-8, MCP-1 IL-1 $\beta$ and TNF- $\alpha$ were quantified with an immunoassay kit (R\&D Systems, Oxford, UK) according to the manufacturer's instructions.

\section{Immunofluorescence flow cytometry}

The levels of surface markers expressed on HUVECs and the procoagulant phenotype of THP-1 cells were assessed using flow cytometry. After $24 \mathrm{~h}$ of coculture or monoculture in the absence or presence of $\mathrm{SiO}_{2}$ particles $(100 \mu \mathrm{g} / \mathrm{mL})$, THP-1 cells were separated and harvested by centrifugation, while HUVEC monolayers, seeded in the 6-well plates, were released from the wells after washing with PBS. The following mouse anti-human monoclonal antibodies were used: ICAM-1 (CD54-PE, eBioscience, San Diego, USA), VCAM-1 (CD106-FITC, BD Biosciences, San Diego, USA), E-selectin (CD62EAPC, BD Biosciences, San Diego, USA), tissue factor (TF) (CD142-PE, BD Biosciences, San Diego, USA), CD11a (Biolegend, San Diego, USA), and vWF ( BD Biosciences, San Diego, USA). In addition, FITC- and APCconjugated antibodies specific for human CD40 and CD40L (BD Biosciences, San Diego, USA), respectively, were also used to determine the expression of the costimulatory molecules on HUVECs and THP-1 cells. After exposure to particles $(100 \mu \mathrm{g} / \mathrm{mL})$ for $24 \mathrm{~h}$, HUVECs and THP-1 cells were collected and labeled with the abovementioned specific antibodies at room temperature (RT) for $45 \mathrm{~min}$ in the dark, washed extensively, and then subsequently fixed with $1 \%$ paraformaldehyde. All samples were analyzed with a BD flow cytometer. The data were analyzed with Cell Quest software.

\section{Western blot analysis}

Total cellular protein extracts were prepared as described in a previous study [49]. Briefly, after a 24-h coculture or monoculture in the absence or presence of $\mathrm{SiO}_{2}$ particles $(100 \mu \mathrm{g} / \mathrm{mL})$, as indicated, HUVECs or THP-1 cells were washed once with ice-cold PBS and lysed in ice-cold lysis buffer [50 mM Tris-HCl, $150 \mathrm{mM}$ $\mathrm{NaCl}, 1 \% \mathrm{NP}-40,0.1 \%$ sodium dodecyl sulfate (SDS), Applygen, Beijing, China] containing $1 \mathrm{mM}$ phenylmethylsulphonyl fluoride (PMSF) (Sigma, St. Louis, MO, USA) and phosphatase inhibitor cocktail (Sigma, St. Louis, MO, USA) for $30 \mathrm{~min}$. After centrifuging the lysates at $12,000 \mathrm{rpm}$ and $4{ }^{\circ} \mathrm{C}$ for $10 \mathrm{~min}$, the supernatants were collected and stored at $-80^{\circ} \mathrm{C}$ until used. The protein concentrations of these extracts were determined by performing a bicinchoninic acid (BCA) protein assay (Pierce, Rockford, USA). Equal amounts of the lysate proteins $(40 \mu \mathrm{g})$ were then loaded onto SDS-polyacrylamide gels (10-12\% separation gels) and electrophoretically transferred to nitrocellulose (NC) membranes (Amersham Biosciences, US). After blocking with $5 \%$ nonfat milk in Tris-buffered saline (TBS) containing $0.05 \%$ Tween-20 (TBST) for $1 \mathrm{~h}$ at RT, the membrane was respectively incubated with anti-p-p38, p-p-JNK, JNK (1:1,000, rabbit polyclonal antibodies, Bioworld Technology, USA), anti-p-38 (1:1,000, rabbit polyclonal antibodies, CST, USA), $\beta$-actin $(1: 1,000$, a mouse polyclonal antibody, Santa Cruz Biotechnology, CA) at $4{ }^{\circ} \mathrm{C}$ overnight, washed with TBST, and incubated with a horseradish peroxidase-conjugated anti-rabbit IgG/anti-mouse IgG secondary antibody at $37^{\circ} \mathrm{C}$ for $1 \mathrm{~h}$. The antibody-bound proteins were detected using the ECL chemiluminescence reagent (Millipore, USA). 


\section{Electrophoretic mobility shift assay (EMSA)}

The EMSA is classically used to detect the activity of transcription factors and relies upon the principle that DNA bound to protein has decreased mobility through a polyacrylamide gel matrix relative to the corresponding free, unbound DNA. In the present study, the NF- $\mathrm{kB}$ activation in HUVECs and THP-1 cells was assessed by EMSA. Briefly, after a 24-h coculture or monoculture in the absence or presence of $\mathrm{SiO}_{2}$ particles $(100 \mu \mathrm{g} / \mathrm{mL})$, as indicated, nuclear extracts of HUVECs or THP-1 cells were prepared as described by the instructions for $\mathrm{Nu}$ clear and Cytoplasmic Extraction Reagents (Pierce, Rockford, USA). Protein concentrations were quantified by the $\mathrm{BCA}$ protein assay. Ten milligrams of nuclear protein was incubated in binding buffer containing $50 \mathrm{ng} / \mu \mathrm{L}$ Poly (dI.dC), 2.5\% Glycerol, 0.05\% NP-40, $5 \mathrm{mM} \mathrm{MgCl} 2$ and 20 fmol Biotin end-labeled oligonucleotides at RT for $20 \mathrm{~min}$. The labeled oligonucleotides had the following sequences: $5^{\prime}$ - AGT TGA GGG GAC TTT CCC AGG C - $3^{\prime}$ and $5^{\prime}$ - GCC TGG GAA AGT CCC CTC AAC T - 3'. Cold competition experiments were performed by adding a 100-fold molar excess of unlabeled oligonucleotides. Protein-DNA complexes were separated from the free DNA probe by electrophoresis through $4 \%$ native polyacrylamide gels. Gels were dried, and then, the protein-DNA complexes were visualized by the ECL chemiluminescence system.

\section{Statistical analysis}

Data were expressed as the mean \pm SD or the mean \pm SEM. Statistical comparisons of the means were performed using one-way analysis of variance (ANOVA) with the software SAS 6.12. The differences were considered to be significant when the $p$ value was less than 0.05 .

\section{Ethical approval}

Ethical approval was given by the independent ethics committee of Shanghai Ninth People's affiliated to Shanghai JiaoTong University, School of Medicine with the following reference number: 2010-43. Written informed consent was obtained from the patient for publication of this report and any accompanying images.

\section{Competing interests}

The authors declare that they have no competing interests.

\section{Authors' contributions}

Jiao sun obtained funding and provided financial support for the research project. The study design was constructed by Xin Liu and Jiao Sun. Xin Liu performed the majority of the experiments and data analysis and drafted the manuscript. Yang Xue and Tingting Ding performed part of the cellular experiments. All of the authors have read and approved the final manuscript.

\section{Acknowledgments}

This work was supported by grants from the Natural Science Foundation of China (no. 30670556, no. 31070843), the Shanghai Sci-Tech Committee Foundation (0752 nm026), the Shanghai Leading Academic Discipline Project (no. S30206), and the Major Program of the National Natural Science Foundation of China (no.81190132).

Received: 25 February 2012 Accepted: 11 September 2012 Published: 18 September 2012

\section{References}

1. Sekhon BS, Kamboj SR: Inorganic nanomedicine-part 1. Nanomedicine 2010, 6(4):516-522.

2. Grandjean-Laquerriere $A$, Laquerriere $P$, Guenounou $M$, Laurent-Maquin $D$, Phillips TM: Importance of the surface area ratio on cytokines production by human monocytes in vitro induced by various hydroxyapatite particles. Biomaterials 2005, 26(15):2361-2369.

3. Wan R, Mo Y, Zhang X, Chien S, Tollerud DJ, Zhang Q: Matrix metalloproteinase- 2 and -9 are induced differently by metal nanoparticles in human monocytes: The role of oxidative stress and protein tyrosine kinase activation. Toxicol Appl Pharmacol 2008, 233(2):276-285.

4. Lee HM, Shin DM, Song HM, Yuk JM, Lee ZW, Lee SH, Hwang SM, Kim JM, Lee CS, Jo EK: Nanoparticles up-regulate tumor necrosis factor-alpha and CXCL8 via reactive oxygen species and mitogen-activated protein kinase activation. Toxicol Appl Pharmacol 2009, 238(2):160-169.

5. Boraschi D, Costantino L, Italiani P: Interaction of nanoparticles with immunocompetent cells: nanosafety considerations. Nanomedicine (Lond) 2012, 7(1):121-131

6. Gojova A, Guo B, Kota RS, Rutledge JC, Kennedy IM, Barakat Al: Induction of inflammation in vascular endothelial cells by metal oxide nanoparticles: effect of particle composition. Environ Health Perspect 2007, 115(3):403-409.

7. Oesterling E, Chopra N, Gavalas V, Arzuaga X, Lim EJ, Sultana R, Butterfield DA, Bachas L, Hennig B: Alumina nanoparticles induce expression of endothelial cell adhesion molecules. Toxicol Lett 2008, 178(3):160-166.

8. Liu X, Sun J: Endothelial cells dysfunction induced by silica nanoparticles through oxidative stress via JNK/P53 and NF-kappaB pathways. Biomaterials 2010, 31(32):8198-8209.

9. Mestas J, Ley K: Monocyte-endothelial cell interactions in the development of atherosclerosis. Trends Cardiovasc Med 2008, 18(6):228-232

10. Gawad A, Ptak-Belowska A, Brzozowski T, Pawlik WW: Monocytes and vascular endothelial cells apoptosis. Role of p-HSP27.J Physiol Pharmacol 2009, 60(4):55-61.

11. Woller G, Brandt E, Mittelstadt J, Rybakowski C, Petersen F: Platelet factor 4/CXCL4-stimulated human monocytes induce apoptosis in endothelial cells by the release of oxygen radicals. J Leukoc Biol 2008, 83(4):936-945.

12. Chakrabarti S, Rizvi M, Pathak D, Kirber MT, Freedman JE: Hypoxia influences CD40-CD40L mediated inflammation in endothelial and monocytic cells. Immunol Lett 2009, 122(2):170-184.

13. Chakrabarti S, Blair P, Freedman JE: CD40-40 L signaling in vascular inflammation. J Biol Chem 2007, 282(25):18307-18317.

14. Li A, Qin L, Zhu D, Zhu R, Sun J, Wang S: Signalling pathways involved in the activation of dendritic cells by layered double hydroxide nanoparticles. Biomaterials 2010, 31(4):748-756.

15. Kim S, Oh WK, Jeong YS, Hong JY, Cho BR, Hahn JS, Jang J: Cytotoxicity of, and innate immune response to, size-controlled polypyrrole nanoparticles in mammalian cells. Biomaterials 2010, 32(9):2342-2350.

16. Benezra M, Penate-Medina O, Zanzonico PB, Schaer D, Ow H, Burns A, DeStanchina E, Longo V, Herz E, lyer S, et al: Multimodal silica nanoparticles are effective cancer-targeted probes in a model of human melanoma. J Clin Invest 2011, 121(7):2768-2780.

17. He Q, Shi J, Chen F, Zhu M, Zhang L: An anticancer drug delivery system based on surfactant-templated mesoporous silica nanoparticles. Biomaterials 2010, 31(12):3335-3346.

18. Swierczewska $M$, Lee $S$, Chen $X$ : Inorganic nanoparticles for multimodal molecular imaging. Mol Imaging 2011, 10(1):3-16.

19. Lankoff A, Sandberg WJ, Wegierek-Ciuk A, Lisowska H, Refsnes M, Sartowska B, Schwarze PE, Meczynska-Wielgosz S, Wojewodzka M, Kruszewski M: The effect of agglomeration state of silver and titanium dioxide nanoparticles on cellular response of HepG2, A549 and THP-1 cells. Toxicol Lett 2012, 208(3):197-213.

20. Drescher D, Orts-Gil G, Laube G, Natte K, Veh RW, Osterle W, Kneipp J: Toxicity of amorphous silica nanoparticles on eukaryotic cell model is 
determined by particle agglomeration and serum protein adsorption effects. Anal Bioanal Chem 2011, 400(5):1367-1373.

21. Gualtieri M, Skuland T, Iversen TG, Lag M, Schwarze P, Bilanicova D, Pojana G, Refsnes M: Importance of agglomeration state and exposure conditions for uptake and pro-inflammatory responses to amorphous silica nanoparticles in bronchial epithelial cells. Nanotoxicology 2011. doi:10.3109/17435390.2011.604441.

22. L'Azou B, Jorly J, On D, Sellier E, Moisan F, Fleury-Feith J, Cambar J, Brochard $P$, Ohayon-Courtes C: In vitro effects of nanoparticles on renal cells. Particle and fibre toxicology 2008, 5:22.

23. Monteiro-Riviere NA, Inman AO, Zhang LW: Limitations and relative utility of screening assays to assess engineered nanoparticle toxicity in a human cell line. Toxicol Appl Pharmacol 2009, 234(2):222-235.

24. Zhao F, Zhao Y, Liu Y, Chang X, Chen C: Cellular Uptake, Intracellular Trafficking, and Cytotoxicity of Nanomaterials. Small 2011, 7(10):1322-1337.

25. Thurn KT, Arora H, Paunesku T, Wu A, Brown EM, Doty C, Kremer J, Woloschak G: Endocytosis of titanium dioxide nanoparticles in prostate cancer PC-3 M cells. Nanomedicine 2011, 7(2):123-130.

26. Al-Rawi M, Diabate S, Weiss C: Uptake and intracellular localization of submicron and nano-sized SiO particles in HeLa cells. Arch Toxicol 2011, 85(7):813-826

27. He Q, Zhang Z, Gao Y, Shi J, Li Y: Intracellular localization and cytotoxicity of spherical mesoporous silica nano- and microparticles. Small 2009, 5(23):2722-2729.

28. Libby P: Inflammation in atherosclerosis. Nature 2002, 420(6917):868-874.

29. Ito T, Ikeda U: Inflammatory cytokines and cardiovascular disease. Curr Drug Targets Inflamm Allergy 2003, 2(3):257-265.

30. Ikeda U, Ikeda M, Oohara T, Oguchi A, Kamitani T, Tsuruya Y, Kano S: Interleukin 6 stimulates growth of vascular smooth muscle cells in a PDGF-dependent manner. Am J Physiol 1991, 260(5 Pt 2):H1713-H1717.

31. Gerszten RE, Garcia-Zepeda EA, Lim YC, Yoshida M, Ding HA, Gimbrone MA Jr, Luster AD, Luscinskas FW, Rosenzweig A: MCP-1 and IL-8 trigger firm adhesion of monocytes to vascular endothelium under flow conditions. Nature 1999, 398(6729):718-723.

32. Zhu MT, Wang B, Wang Y, Yuan L, Wang HJ, Wang M, Ouyang H, Chai ZF, Feng WY, Zhao YL: Endothelial dysfunction and inflammation induced by iron oxide nanoparticle exposure: Risk factors for early atherosclerosis. Toxicol Lett 2011, 203(2):162-171.

33. Alfaro-Moreno E, Nawrot TS, Vanaudenaerde BM, Hoylaerts MF, Vanoirbeek JA, Nemery B, Hoet PH: Co-cultures of multiple cell types mimic pulmonary cell communication in response to urban PM10. Eur Respir $\lrcorner$ 2008, 32(5):1184-1194

34. Herseth Jl, Refsnes M, Lag M, Schwarze PE: Role of IL-1 beta and COX2 in silica-induced IL-6 release and loss of pneumocytes in co-cultures. Toxicol In Vitro 2009, 23(7):1342-1353.

35. Kasper J, Hermanns Ml, Bantz C, Maskos M, Stauber R, Pohl C, Unger RE, Kirkpatrick JC: Inflammatory and cytotoxic responses of an alveolarcapillary coculture model to silica nanoparticles: Comparison with conventional monocultures. Part Fibre Toxicol 2011, 8(1):6.

36. Lee S, Yun HS, Kim SH: The comparative effects of mesoporous silica nanoparticles and colloidal silica on inflammation and apoptosis. Biomaterials 2011, 32(35):9434-9443.

37. Park EJ, Park K: Oxidative stress and pro-inflammatory responses induced by silica nanoparticles in vivo and in vitro. Toxicol Lett 2009, 184(1):18-25.

38. Chu AJ: Tissue factor upregulation drives a thrombosis-inflammation circuit in relation to cardiovascular complications. Cell Biochem Funct 2006, 24(2):173-192.

39. Tavano R, Segat D, Reddi E, Kos J, Rojnik M, Kocbek P, Iratni S, Scheglmann $D$, Colucci M, Echevarria IM, et al: Procoagulant properties of bare and highly PEGylated vinyl-modified silica nanoparticles. Nanomedicine (Lond) 2010, 5(6):881-896

40. Neumann FJ, Ott I, Marx N, Luther T, Kenngott S, Gawaz M, Kotzsch M, Schomig A: Effect of human recombinant interleukin-6 and interleukin-8 on monocyte procoagulant activity. Arterioscler Thromb Vasc Biol 1997, 17(12):3399-3405.

41. Kristovich R, Knight DA, Long JF, Williams MV, Dutta PK, Waldman WJ: Macrophage-mediated endothelial inflammatory responses to airborne particulates: impact of particulate physicochemical properties. Chem Res Toxicol 2004, 17(10):1303-1312
42. Wagner AH, Guldenzoph B, Lienenluke B, Hecker M: CD154/CD40-mediated expression of CD154 in endothelial cells: consequences for endothelial cell-monocyte interaction. Arterioscler Thromb Vasc Biol 2004, 24(4):715-720.

43. Kalyanaraman B, Darley-Usmar V, Davies KJ, Dennery PA, Forman HJ, Grisham MB, Mann GE, Moore K, Roberts LJ 2nd, Ischiropoulos H: Measuring reactive oxygen and nitrogen species with fluorescent probes: challenges and limitations. Free Radic Biol Med 2012, 52(1):1-6.

44. Eom HJ, Choi J: Oxidative stress of $\mathrm{CeO} 2$ nanoparticles via p38-Nrf-2 signaling pathway in human bronchial epithelial cell, Beas-2B. Toxicol Lett 2009, 187(2):77-83.

45. Xia T, Kovochich M, Brant J, Hotze M, Sempf J, Oberley T, Sioutas C, Yeh J, Wiesner MR, Nel AE: Comparison of the abilities of ambient and manufactured nanoparticles to induce cellular toxicity according to an oxidative stress paradigm. Nano Lett 2006, 6(8):1794-1807.

46. Wu J, Wang C, Sun J, Xue Y: Neurotoxicity of silica nanoparticles: brain localization and dopaminergic neurons damage pathways. ACS Nano 2011, 5(6):4476-4489.

47. Hoefen RJ, Berk BC: The role of MAP kinases in endothelial activation. Vascul Pharmacol 2002, 38(5):271-273

48. Jaffe EA, Nachman RL, Becker CG, Minick CR: Culture of human endothelial cells derived from umbilical veins. Identification by morphologic and immunologic criteria. J Clin Invest 1973, 52(11):2745-2756.

49. Chen YH, Lin SJ, Ku HH, Shiao MS, Lin FY, Chen JW, Chen YL: Salvianolic acid $B$ attenuates VCAM-1 and ICAM-1 expression in TNF-alpha-treated human aortic endothelial cells. J Cell Biochem 2001, 82(3):512-521.

doi:10.1186/1743-8977-9-36

Cite this article as: Liu et al:: Enhancement of proinflammatory and procoagulant responses to silica particles by monocyte-endothelial cell interactions. Particle and Fibre Toxicology 2012 9:36.

\section{Submit your next manuscript to BioMed Central and take full advantage of:}

- Convenient online submission

- Thorough peer review

- No space constraints or color figure charges

- Immediate publication on acceptance

- Inclusion in PubMed, CAS, Scopus and Google Scholar

- Research which is freely available for redistribution 